\title{
PROFIL KASUS KEKERASAN SEKSUAL DI RUMAH SAKIT UMUM PUSAT Dr. M. DJAMIL PADANG PERIODE 2012-2016
}

\author{
Taufik Hidayat, Rika Susanti, Citra Manela, Noverika Winda Sari, Abdullah Arief Syahputra \\ Bagian / KSM Ilmu Kedokteran Forensik Fakultas Kedokteran Unand / RSUP dr. M. Djamil \\ Padang \\ Jln.Perintis Kemerdekaan No 94 POBOX 49 Padang 25127, Sumatera Barat, Indonesia \\ taufikhidayat@med.unand.ac.id
}

\begin{abstract}
ABSTRAK.
Latar belakang Ilmu kedokteran forensik sangat berperan dalam upaya pembuktian hukum adanya tindak pidana kekerasan seksual. Tujuan penelitian adalah untuk mengetahui profil kasus, korban dan pelaku kekerasan seksual yang diperiksa di Rumah Sakit Umum Pusat dr. M. Djamil Padang. Metode Rancangan penelitian menggunakan metode deskriptif. Data diperoleh dari rekam medik kasus kekerasan seksual yang diperiksa di Rumah Sakit Umum Pusat Dr. M. Djamil Padang dari tahun 2012 sampai 2016. Hasil Kejadian kekerasan seksual terbanyak tahun 2015 dan yang paling sedikit adalah pada tahun 2013. Jenis kekerasan seksual terbanyak yang ditemukan adalah perkosaan $(39,3 \%)$. Anak-anak merupakan korban tersering $(76,4 \%)$. Korban terbanyak adalah pelajar SMP (22,9\%). Hampir sebagian besarnya tidak mengakibatkan kehamilan $(92,1 \%)$. Didapatkan selaput dara utuh $(17,1 \%)$, robekan lama $(54,3 \%)$, robekan baru $(10 \%)$ dan yang membutuhkan perawatan medis sejumlah 1 kasus $(0.7 \%)$. Pemeriksaaan anus pada 6 kasus dan ditemukan 1 korban dengan kemerahan. Pada 9 korban (6.4\%) ditemukan adanya sperma. Hasil pemeriksaan genitalia luar didapatkan kemerahan (15\%), luka robek (5\%), tidak terdapat luka $(70,7 \%)$ dan luka lecet sebanyak (9,3\%). Didapatkan 9 kasus yang dilakukan pemeriksaan tanda kekerasan dan ditemukan adanya luka memar pada 5 korban (3.6\%), luka lecet pada 2 korban (1.4\%), dan luka terbuka pada 1 korban $(0.7 \%)$. Usia pelaku terbanyak pada penelitian ini adalah dewasa (59,3\%). Pacar adalah pelaku kekerasan seksual terbanyak (27.1\%). Kesimpulan Pada penelitian ini didapatkan bahwa kasus kekerasan seksual terbanyak adalah perkosaan dan korban sebagian besar adalah anak-anak. Ditemukan tanda-tanda kekerasan pada sebagian besar kasus dan pelaku terbanyak adalah pacar.
\end{abstract}

Kata kunci: kekerasan seksual, perkosaan, forensik

\begin{abstract}
Background Forensic medicine plays an important role in solving the case of sexual violence. The objective of this study was to determine the profile of cases, victims and perpetrators of sexual violence who were examined in Dr. M. Djamil general hospital of Padang. Method The design of the study was descriptive. Data were obtained from medical records of sexual violence cases in Dr. M. Djamil general hospital from 2012 to 2016. Results. The highest number of sexual violence incident was in 2015 and the lowest was in 2013. The highest type of sexual violence was rape (39.3\%). Children were the most frequent victims (76.4\%). Most of the victims were junior high school students $(22.9 \%)$. Most of the victims were not pregnant $(92.1 \%)$ while hymen remains intact was about $17.1 \%$, old torn $(54.3 \%)$, new torn $(10 \%)$ and 1 cases requires medical treatment $(0.7 \%)$. We were conducted anal examination in 6 cases and found redness of anal in 1 case. We were conducted sperm and semen analysis and found sperm in 9 vaginal swab of the victims $(6.4 \%)$. We found redness of external genitalia (15\%), laceration (5\%), and abrasions $(9.3 \%)$ and no injuries $(70.7 \%)$ There were 9 cases that show the signs of violence, bruises in 5 victims (3.6\%), abrasions in 2 victims $(1.4 \%)$, and laceration in 1 victim $(0.7 \%)$. The age of most perpetrators in this study was adults $(59.3 \%)$. Closefriend is probably the perpetrators of sexual violence $(27.1 \%)$. Conclusion In this study rape is the most sexual violence cases and the majority of victims were children. Signs of violence were found in most cases and most perpetrators were closefriends.
\end{abstract}

Keywords: sexual violence, rape, forensic 


\section{PENDAHULUAN}

Kekerasan seksual merupakan setiap penyerangan bersifat seksual, baik dengan adanya persetubuhan maupun tidak, tanpa mempedulikan hubungan antara pelaku dengan korban. Hal ini tidak hanya menimpa perempuan dewasa, perempuan yang tergolong di bawah umur (anak-anak) kerap juga menjadi korban. Kekerasan atau kekerasan seksual dapat dilakukan dengan paksaan atau tanpa paksaan, baik dengan kekerasan fisik ataupun ancaman melakukan kekerasan. Kekerasan seksual tanpa unsur paksaan biasanya dilakukan dengan cara membujuk atau melakukan tindakan lain dengan tujuan memperdaya korban dan hal ini sering terjadi pada anak-anak karena keterbatasan pengalaman dan penalaran berpikir. Sedangkan kekerasan seksual dengan unsur pemaksaan dikenal dengan istilah perkosaan. [2]

Terdapat beberapa arti kata dari kekerasan seksual, baik arti kata secara legal, sosial, maupun medis. Salah satu pengertian kekerasan seksual adalah sebagai segala jenis bentuk perbuatan atau hubungan seksual dengan/tanpa paksaan dan tanpa persetujuan (consent) dari korban. [4],[5] Sedangkan arti kata yang lain menyamakan kekerasan seksual dengan perkosaan (rape) disertai adanya persetubuhan, yaitu penetrasi penis (alat kelamin pria) ke dalam vagina (alat kelamin wanita). [6],[7] WHO dalam World Report on Violence and Health menyampaikan bahwa kekerasan seksual merupakan setiap tindakan seksual, usaha melakukan perbuatan seksual, ucapan mengarah seksual yang tidak diinginkan dan diarahkan kepada aspek seksualitas seseorang dengan paksaan terlepas hubungan korban, dimanapun, tidak hanya terbatas pada lingkungan rumah dan pekerjaan. [19]

\section{METODE}

Rancangan penelitian menggunakan metode deskriptif. Data diambil dari rekam medik semua kasus kekerasan seksual yang diperiksa di Bagian/KSM Ilmu Kedokteran Forensik Fakultas Kedokteran Universitas Andalas/Rumah Sakit Umum Pusat Dr. M. Djamil Padang dari Januari 2012 sampai dengan Desember 2016. Instrumen penelitian menggunakan SPSS 20.00 untuk mengolah data yang diperoleh. Data disajikan dalam bentuk frekuensi dan persentase.

\section{HASIL dan PEMBAHASAN} Profil kasus kekerasan seksual Grafik 1. Distribusi Frekuensi Kasus Kekerasan Seksual Periode 1 Januari 2012-31 Desember 2016 Berdasarkan Tahun Kejadian.

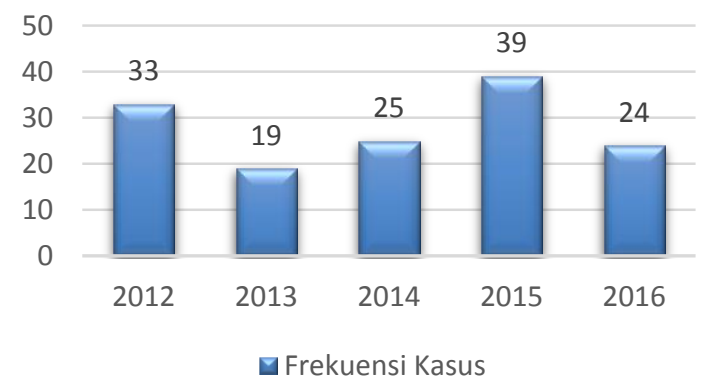

Persentase jumlah kasus terbanyak tercatat pada tahun 2015 (27.9\%) dan yang paling sedikit adalah pada tahun 2013 (13.6\%).

37 Taufik Hidayat, Rika Susanti, Citra Manela, Noverika Winda Sari, Abdullah Arief Syahputra Bagian / KSM Ilmu Kedokteran Forensik Fakultas Kedokteran Unand / RSUP dr. M. Djamil 
Selama periode 2012-2016 terjadi variasi penaikan dan penurunan kasus kekerasan seksual. Serupa dengan penelitian lainnya dimana kejadian kasus kekerasan seksual Grafik 2. Distribusi Frekuensi Kasus Kekerasan Seksual Periode 1 Januari 2012-31 Desember 2016 Berdasarkan Usia Korban.

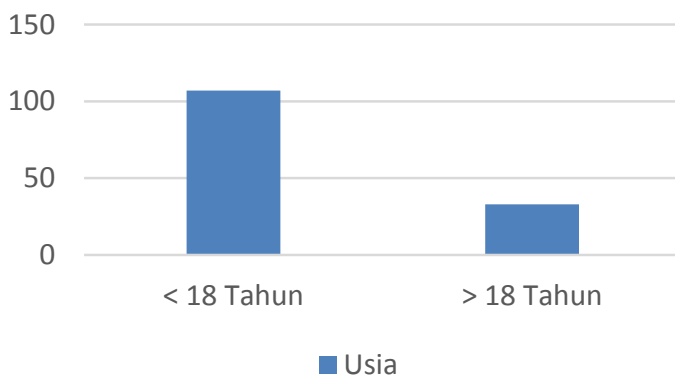

Pada grafik 2 terlihat bahwa kasus kekerasan seksual terhadap anak $(76,4 \%)$ lebih banyak terjadi dibandingkan pada dewasa. Sebaliknya, pelaku dewasa $(59,3 \%)$ lebih banyak dibandingkan anak.

Diagram 1. Distribusi Frekuensi Kasus Kekerasan Seksual Periode 1 Januari 2012-31 Desember 2016 Berdasarkan Jenis Kekerasan

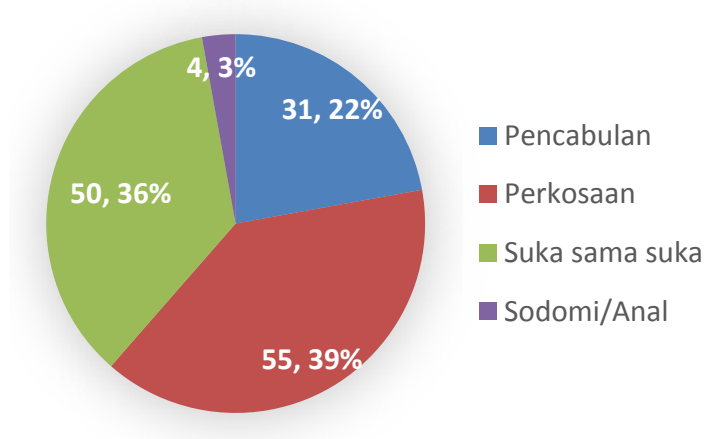

Seksual

Jenis kekerasan seksual terbanyak di RSUP Dr. M. Djamil Padang adalah perkosaan $(39,3 \%)$ diikuti suka sama suka sebanyak bervariasi dari tahun ke tahun. [20][21]

$(35,7 \%)$, cabul $(22,1 \%)$ dan sodomi atau anal $(2,9 \%)$. Berdasarkan pasal 285 KUHP dimana perkosaan harus terdapat bukti persetubuhan, paksaan dengan atau tanpa bukti kekerasan. Pencabulan diatur dalam KUHP pasal 289-296. Hasil ini berbeda dengan penelitian lainnya dimana didapatkan jenis kekerasan seksual terbanyak pencabulan sebanyak 95,83\%. [20]

Tabel 1. Distribusi Frekuensi Kasus Kekerasan Seksual Periode 1 Januari 2012-31 Desember 2016 Berdasarkan Jenis Ancaman / Kekerasan.

\begin{tabular}{ccc}
\hline $\begin{array}{c}\text { Jenis } \\
\text { Kekerasan }\end{array}$ & Frekuensi & \% \\
\hline Dipukul & 9 & 6.4 \\
Dibekap & 1 & 0.7 \\
Diremas & 1 & 0.7 \\
Verbal & 22 & 15.7 \\
Tidak Ada & 67 & 47.9 \\
Tidak Diketahui & 24 & 17.1 \\
Diberi Minuman & 8 & 5.7 \\
Senjata Tajam & 4 & 2.9 \\
Diikat & 3 & 2.1 \\
Hipnotis & 1 & 0.7 \\
Total & 140 & 100 \\
\hline
\end{tabular}

Pada tabel 1 diketahui bahwa jenis ancaman atau kekerasan yang dilakukan pelaku terhadap korban terbanyak adalah tidak ada ancaman atau kekerasan (47.9\%) dan yang paling sedikit adalah dibekap, diremas dan dihipnotis $(0.7 \%)$.

38 Taufik Hidayat, Rika Susanti, Citra Manela, Noverika Winda Sari, Abdullah Arief Syahputra Bagian / KSM Ilmu Kedokteran Forensik Fakultas Kedokteran Unand / RSUP dr. M. Djamil Padang Sumatera Barat Indonesia 
Tabel 2. Distribusi Frekuensi Kasus Kekerasan Seksual Periode 1 Januari 2012-31 Desember 2016 Berdasarkan TKP

\begin{tabular}{ccc}
\hline TKP & Frekuensi & \% \\
\hline Rumah & 21 & 15 \\
Korban & & \\
Semak & 3 & 2.1 \\
Rumah & 9 & 6.4 \\
Kosong & & \\
Rumah & 29 & 20.7 \\
Pelaku & & \\
Rumah & 6 & 4.3 \\
Kawan & & \\
Tempat & 34 & 24.3 \\
Lain & & 15 \\
Tidak & 21 & \\
Diketahui & & 1.4 \\
Diatas & 2 & 5 \\
Angkot & & 0.7 \\
Hotel & 7 & 5 \\
WC Masjid & 1 & 100 \\
Pinggir & 7 & \\
Sungai & & \\
Total & 140 & \\
\hline
\end{tabular}

Data mengenai tempat kejadian perkara (TKP) kasus kekerasan seksual pada penelitian ini didapatkan persentase terbanyak lokasi TKP adalah tempat lainnya yang tidak disebutkan lokasinya (24.3\%). Sedangkan lokasi yang paling sedikit adalah WC masjid $(0.7 \%)$. Pada penelitian terkait kekerasan seksual yang terjadi pada anak didapatkan pelaku terbanyak adalah orang yang telah dikenal korban dan lokasi kejadian terbanyak bertempat di rumah korban atau rumah pelaku. [23]

\section{Profil korban kekerasan seksual}

Tabel 3. Distribusi Frekuensi Kasus Kekerasan Seksual Periode 1 Januari 2012-31 Desember 2016 Berdasarkan Pendidikan Korban.

\begin{tabular}{ccc}
\hline Pendidikan & Frekuensi & $\%$ \\
\hline Belum & 12 & 8.6 \\
Sekolah & & \\
Paud & 2 & 1.4 \\
SD & 26 & 18.6 \\
SDLB & 1 & 0.7 \\
Tidak tamat & 4 & 2.9 \\
SD & & \\
Tamatan SD & & 7.9 \\
& & \\
& & \\
& 11 & \\
SMP & 32 & 22.9 \\
Tamatan & 2 & 1.4 \\
SMP & & \\
SMA & 20 & 14.3 \\
Tamatan & 11 & 7.9 \\
SMA & & \\
PT & 7 & 5.0 \\
Tidak & 1 & 0.7 \\
Sekolah & & \\
Tidak & 11 & 7.9 \\
Diketahui & & \\
Total & 140 & 100.0 \\
\hline
\end{tabular}

Sebanyak 86 orang $(61,4 \%)$ korban kekerasan seksual berstatus sebagai pelajar, khususnya pelajar SMP (22,9\%), sejalan dengan prevalensi usia korban terbanyak yaitu 15 tahun. Penelitian di Rumah Sakit Bhayangkara Dumai tahun 2009-2013 menemukan hal serupa dimana 71 orang $(59,17 \%)$ korban yang diperiksa berstatus sebagai pelajar, dengan prevalensi usia terbanyak adalah 0-18 tahun. [20] Hasil penelitian ini mempunyai hasil yang berjalan seiringan dengan penelitian di Denmark yang menyebutkan bahwa sebanyak 187

39 Taufik Hidayat, Rika Susanti, Citra Manela, Noverika Winda Sari, Abdullah Arief Syahputra Bagian / KSM Ilmu Kedokteran Forensik Fakultas Kedokteran Unand / RSUP dr. M. Djamil Padang Sumatera Barat Indonesia 
dari 423 korban kekerasan seksual berstatus sebagai pelajar. [30]

Tabel 4. Distribusi Frekuensi Kasus Kekerasan Seksual Periode 1 Januari 2012-31 Desember 2016 Berdasarkan Pekerjaan Korban.

\begin{tabular}{ccc}
\hline Pekerjaan & Frekuensi & \% \\
\hline $\begin{array}{c}\text { Belum } \\
\text { bekerja }\end{array}$ & 30 & 21.4 \\
Pelajar & 86 & 61.4 \\
Tidak & 12 & 8.6 \\
diketahui & & 5.0 \\
Mahasiswi & 7 & 3.6 \\
Bekerja & 5 & 100.0 \\
Total & 140 &
\end{tabular}

Pada tabel 4 terlihat bahwa pelajar merupakan target kekerasan seksual terbanyak $(61,4 \%)$. Sedangkan perempuan yang telah bekerja merupakan target kekerasan seksual yang paling sedikit (3.6\%).

Grafik 3. Distribusi Frekuensi Kasus Kekerasan Seksual Periode 1 Januari 2012-31 Desember 2016 Berdasarkan Kehamilan.

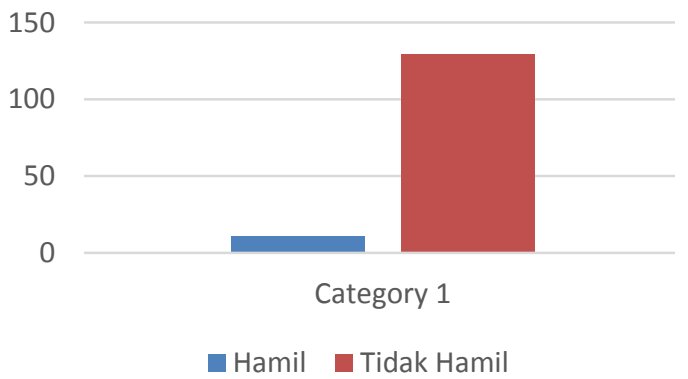

Berdasarkan terjadi atau tidaknya kehamilan akibat kekerasan seksual, penelitian ini menunjukkan bahwa dari 140 total kasus kekerasan seksual yang dilaporkan, hampir sebagian besarnya tidak mengakibatkan kehamilan yaitu sebanyak 129 kasus $(92,1 \%)$. Hal ini mungkin terjadi disebabkan oleh beberapa hal seperti tidak sampai terjadi persetubuhan, korban atau pelaku belum pubertas, pemeriksaan yang dilakukan segera setelah kejadian dan lain sebagainya.

\section{Temuan pemeriksaan fisik dan genitalia korban}

Tabel 5. Distribusi Frekuensi Kasus Kekerasan Seksual Periode 1 Januari 2012-31 Desember 2016 Berdasarkan Pemeriksaan Genitalia Eksterna.

\begin{tabular}{ccc}
\hline $\begin{array}{c}\text { Genitalia } \\
\text { Eksterna }\end{array}$ & Frekuensi & \% \\
\hline Memar & 21 & 15.0 \\
Luka robek & 7 & 5.0 \\
Luka lecet & 13 & 9.3 \\
Tidak ada & 99 & 70.7 \\
luka & & \\
Total & 140 & 100.0 \\
\hline
\end{tabular}

Dari data hasil pemeriksaan genitalia luar ditemukan tidak terdapat luka pada genitalia luar sebagian besar korban kekerasan seksual pada penelitian ini (70.7\%). Sedangkan sebagian kecil korban ditemukan luka berupa kemerahan $(15 \%)$, luka lecet $(9.3 \%)$ atau luka robek $(5 \%)$.

Tabel 6. Distribusi Frekuensi Kasus Kekerasan Seksual Periode 1 Januari 2012-31 Desember 2016 Berdasarkan Pemeriksaan Selaput dara.

\begin{tabular}{ccc}
\hline Selaput Dara & Frekuensi & \% \\
\hline Utuh & 24 & 17.1 \\
Robekan Lama & 40 & 28.6 \\
Hingga Dasar & & \\
\hline
\end{tabular}

40 Taufik Hidayat, Rika Susanti, Citra Manela, Noverika Winda Sari, Abdullah Arief Syahputra Bagian / KSM Ilmu Kedokteran Forensik Fakultas Kedokteran Unand / RSUP dr. M. Djamil Padang Sumatera Barat Indonesia 


\begin{tabular}{lcc}
$\begin{array}{l}\text { Robekan Lama Tidak } \\
\text { Sampai Dasar }\end{array}$ & 36 & 25.7 \\
$\begin{array}{c}\text { Robekan Baru Sampai } \\
\text { ke Dasar }\end{array}$ & 9 & 6.4 \\
$\begin{array}{c}\text { Robekan Baru Tidak } \\
\text { Sampai ke Dasar }\end{array}$ & 5 & 3.6 \\
$\quad$ Kemerahan & 4 & 2.9 \\
$\quad$ Campuran & 21 & 15 \\
Ada Perawatan Medis & 1 & 0.7 \\
Total & 140 & 100 \\
\hline
\end{tabular}

Di RSUP dr M. Djamil berdasarkan pemeriksaan selaput dara pada seluruh korban perempuan didapatkan hasil selaput dara utuh $17,1 \%$, robekan lama $54,3 \%$, robekan baru $10 \%$ dan yang membutuhkan perawatan medis sejumlah 1 kasus (0.7\%). Sesuai dengan penelitian di RSUD Sanglah dimana terdapat tanda penetrasi pada $78 \%$ kasus dan tanda penetrasi paling banyak yaitu robekan lama dan tanpa perlukaan pada kelamin luar 78,7\%. [21] Adanya suatu perbuatan kekerasan seksual adalah peristiwa yang sulit dibuktikan walaupun pada kasus tersebut telah diterapkan berbagai pemeriksaan dan pengumpulan barang bukti dalam menegakkan ada atau tidaknya persetubuhan. [32] Pemeriksaan korban curiga persetubuhan terduga kasus kekerasan seksual, umumnya pemeriksaan dilakukan oleh dokter ahli ilmu kebidanan dan penyakit kandungan, kecuali pada lingkungan terjadinya kasus tersebut tidak terdapat dokter ahli yang dibutuhkan, maka dokter umum yang akan melakukan pemeriksaan terkait kasus tersebut. [33] Kepustakaan menyebutkan bahwa korban hidup diperiksa dokter spesialis kebidanan dan penyakit kandungan lalu korban meninggal dunia, maka akan diserahkan kepada dokter forensik dengan seluruh hasil pemeriksaan dituangkan kedalam Visum et Repertum. [34]

Selain melakukan anamnesis, bagian forensik juga melakukan pemeriksaan fisik pada korban kekerasan seksual. Pemeriksaan meliputi pemeriksaan genitalia luar, selaput dara, anus, keterlibatan benda asing dan tanda-tanda kekerasan pada korban. Keterlibatan benda asing dalam kekerasan seksual jarang dilaporkan. Pada suatu penelitian selama 8 tahun didapatkan 20 kasus kekerasan seksual dengan penggunaan benda asing dimana paling banyak ditemukan tutup botol minuman dengan penetrasi terbanyak vagina. [34],[35] Pada penelitian ini didapatkan penggunaan lidi dalam satu kasus. Penggunaan benda asing pada kekerasan seksual sering menyebabkan komplikasi. Pada suatu laporan kasus kekerasaan seksual dengan benda asing menyebabkan fistula rectovaginal. [36]

Tabel 7. Distribusi Frekuensi Kasus Kekerasan Seksual Periode 1 Januari 2012-31 Desember 2016 Berdasarkan Pemeriksaan Anus.

\begin{tabular}{ccc}
\hline Anus & Frekuensi & Persentase \\
\hline Tidak & 134 & 95.7 \\
Diperiksa & & \\
Tidak Ada & 5 & 3.6 \\
Kelainan & & \\
Kemerahan & 1 & 0.7 \\
Total & 140 & 100 \\
\hline
\end{tabular}

41 Taufik Hidayat, Rika Susanti, Citra Manela, Noverika Winda Sari, Abdullah Arief Syahputra Bagian / KSM Ilmu Kedokteran Forensik Fakultas Kedokteran Unand / RSUP dr. M. Djamil Padang Sumatera Barat Indonesia 
Pada 6 korban juga dilakukan pemeriksaaan pada anus korban, dengan hasil tidak ditemukan adanya kelainan $(3.6 \%)$ dan ditemukan adanya kemerahan pada anus $(0.7 \%)$.

Tabel 8. Distribusi Frekuensi Kasus Kekerasan Seksual Periode 1 Januari 2012-31 Desember 2016 Berdasarkan Pemeriksaan Tanda Kekerasan.

\begin{tabular}{ccc}
\hline $\begin{array}{c}\text { Tanda } \\
\text { Kekerasan }\end{array}$ & Frekuensi & \% \\
\hline Tidak & 131 & 93.6 \\
Dilakukan & & \\
Tidak Ada & 1 & 0.7 \\
Memar & 5 & 3.6 \\
Luka Lecet & 2 & 1.4 \\
Luka & 1 & 0.7 \\
Terbuka & & \\
Total & 140 & 100 \\
\hline
\end{tabular}

Pada korban-korban yang dicurigai adanya keterlibatan kekerasan selain kekerasan seksual juga dilakukan pemeriksaan tandatanda kekerasan. Pada tabel 14 terlihat bahwa dari 9 kasus yang dicurigai adanya kekerasan, ditemukan adanya luka memar (3.6\%), luka lecet (1.4\%) dan luka terbuka $(0.7 \%)$. Keterlibatan kekerasan dilakukan dengan menilai adanya tanda kekerasan. Namun terdapatnya tanda-tanda kekerasan pada tubuh korban tidak harus dikarenakan adanya tindakan paksaan, dapat pula disebabkan oleh karena ada hal lain yang tidak berhubungan dengan paksaan. Sehingga dokter, baik umum atau spesialis, pada hakekatnya tidak dapat membuktikan adanya unsur paksaan untuk memenuhi perkosaan seperti dalam pasal 285 KUHP. Pada VeR hanya mencantumkan terdapat atau tidak terdapatnya persetubuhan, tanda-tanda kekerasan serta jenis kekerasan penyebabnya. [33]

Tabel 9. Distribusi Frekuensi Kasus Kekerasan Seksual Periode 1 Januari 2012-31 Desember 2016 Berdasarkan Pemeriksaan Laboratorium Sperma.

\begin{tabular}{ccc}
\hline Lab & Frekuensi & $\%$ \\
\hline Sperma & & 6.4 \\
Ada & 9 & 18.6 \\
Tidak Ada & 26 & 75 \\
Tidak & 105 & \\
Dilakukan & & 100 \\
Total & 140 & \\
\hline
\end{tabular}

Bukti adanya persetubuhan dapat dinilai dengan adanya tanda penetrasi dan ejakulasi, salah satunya dengan pemeriksaan sperma maupun komponen mani. Pada penelitian ini tidak dilakukan pemeriksaan laboratorium sperma pada 105 korban (75\%). Pada 35 korban yang dilakukan pemeriksaan laboratorium ditemukan adanya sperma pada 9 korban $(6.4 \%)$ dan pada 26 korban (18.6\%) lainnya tidak ditemukan adanya sperma. Pada penelitian di RSUD Sanglah didapatkan $85,6 \%$ kasus yang tidak menunjukkan penemuan sel mani serta komponennya. [21]

\section{Profil pelaku kekerasan seksual}

Pada anamnesis juga ditanyakan mengenai pelaku kepada korban. Hal-hal yang ditanyakan meliputi jumlah pelaku, usia pelaku, pendidikan pelaku, pekerjaan

42 Taufik Hidayat, Rika Susanti, Citra Manela, Noverika Winda Sari, Abdullah Arief Syahputra Bagian / KSM Ilmu Kedokteran Forensik Fakultas Kedokteran Unand / RSUP dr. M. Djamil Padang Sumatera Barat Indonesia 
peelaku, hubungan pelaku dengan korban, dan frekuensi berhubungan badan dengan pelaku sebelumnya. Dari data yang didapatkan dari korban didapatkan jumlah pelaku terbanyak adalah 1 orang $(85,7 \%)$. Sedangkan jumlah pelaku yang paling sedikit adalah lebih dari 1 orang $(14,3 \%)$.

Grafik 4. Distribusi Frekuensi Kasus Kekerasan Seksual Periode 1 Januari 2012-31 Desember 2016

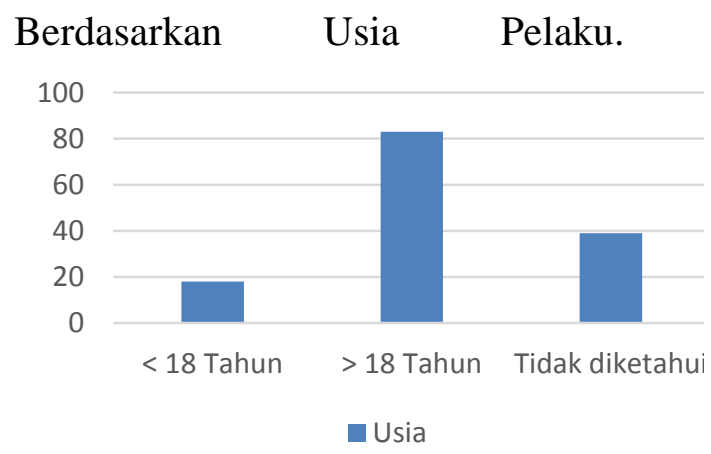

Pada penelitian ini didapatkan usia pelaku yang sangat bervariasi, walaupun sebagian besar pelaku berusia di atas 18 tahun. Namun jika dibagi berdasarkan dekade kehidupan maka usia pelaku yang terbanyak pada penelitian ini adalah pada rentang $11-20$ tahun $(32,1 \%$ $\mathrm{n}=45$ ) dan yang paling sedikit adalah pada rentang 0-10 tahun $(1.4 \% \mathrm{n}=2)$.

Tabel 10. Distribusi Frekuensi Kasus Kekerasan Seksual Periode 1 Januari 2012-31 Desember 2016 Berdasarkan Pendidikan Pelaku.

\begin{tabular}{ccc}
\hline $\begin{array}{c}\text { Pendidikan } \\
\text { Pelaku }\end{array}$ & Frekuensi & \% \\
\hline Tidak Sekolah & 1 & 0.7 \\
Tidak Tamat SD & 3 & 2.1 \\
SD & 2 & 1.4 \\
Tamat SD & 14 & 10 \\
\hline
\end{tabular}

\begin{tabular}{ccc}
\hline SMP & 4 & 2.9 \\
Tamat SMP & 6 & 4.3 \\
SMA & 8 & 5.7 \\
Tamat SMA & 17 & 12.1 \\
Tamatan D3 & 1 & 0.7 \\
PT & 2 & 1.4 \\
Tamat PT & 2 & 1.4 \\
Tidak Diketahui & 80 & 57.1 \\
Total & 140 & 100 \\
\hline
\end{tabular}

Dari data pasien yang diambil kebanyakan pelaku tidak diketahui tingkat pendidikannya (57.1\%). Dari data yang diketahui tingkat pendidikannya, sebagian besar pelaku merupakan tamatan SMA $(12.1 \%)$ dan yang paling sedikit adalah tidak sekolah dan tamatan D3 $(0,7 \%)$. Tingkat pendidikan dan jenis pekerjaan pelaku pada penelitian ini sebagian besar tidak diketahui. Sedangkan dari data yang diketahui mengenai tingkat pendidikan, sebagian besar pelaku merupakan tamatan SMA $(12,1 \%)$, sedangkan untuk jenis pekerjaan yang diketahui diantaranya bekerja sebagai supir, pelajar, dan swasta. Penelitian serupa tahun 2011 diperoleh pendidikan terakhir pelaku terbesar adalah tidak diketahui dan urutan kedua adalah tamatan SMA. [39] Meski ditengarai bahwa pendidikan pelaku tindak kekerasan kebanyakan adalah rendah karena cenderung bersikap kurang bijak dalam menyikapi masalah, memiliki cara pandang yang terbatas dan tidak berpikir panjang tentang risiko dan akibat dari perilakunya serta menganggap bahwa sikap dan perilaku mereka dianggap tidak diperhatikan oleh orang lain sehingga memunculkan sikap acuh tak acuh dalam kesehariannya. [40] Sedangkan dalam hal pekerjaan pelaku,

43 Taufik Hidayat, Rika Susanti, Citra Manela, Noverika Winda Sari, Abdullah Arief Syahputra Bagian / KSM Ilmu Kedokteran Forensik Fakultas Kedokteran Unand / RSUP dr. M. Djamil 
kepustakaan menunjukkan pekerjaan terbanyak pelaku adalah swasta. [22] Penelitian lain yang mendukung temuan ini mengungkapkan bahwa pelaku kekerasan seksual tidak didominasi oleh pelaku yang berasal dari golongan ekonomi menengah atau kekurangan, tidak berpendidikan atau tidak bekerja, melainkan pelakunya dapat menempati seluruh strata sosial dari yang terendah hingga strata sosial tertinggi. [29]

Tabel 11. Distribusi Frekuensi Kasus Kekerasan Seksual Periode 1 Januari 2012-31 Desember 2016 Berdasarkan Pekerjaan Pelaku.

\begin{tabular}{ccc}
\hline $\begin{array}{c}\text { Pekerjaan } \\
\text { Pelaku }\end{array}$ & Frekuensi & \% \\
\hline Pelajar & 15 & 10.7 \\
Pembantu & 1 & .7 \\
Kantin & & \\
Petugas & 1 & .7 \\
Bandara & & \\
Pemotong & 1 & .7 \\
Kayu & & \\
Pedagang & 5 & 3.6 \\
Kenek & 2 & 1.4 \\
Petugas Cuci & 1 & .7 \\
Mobil & & \\
Pemulung & 1 & .7 \\
Kuli & 7 & 5.0 \\
Karyawan & 1 & .7 \\
Tentara & 1 & .7 \\
Mahasiswa & 3 & 2.1 \\
Tidak Bekerja & 14 & 10.0 \\
Swasta & 15 & 10.7 \\
Tani & 8 & 5.7 \\
Sopir & 16 & 11.4 \\
Tidak & 45 & 32.1 \\
Diketahui & & \\
Dukun & 3 & 2.1 \\
Total & 140 & 100.0 \\
\hline
\end{tabular}

Tabel 11 telah memberikan data bahwa sebagian besar pekerjaan pelaku yang tidak ketahui $(32,1 \%)$. Sedangkan dari data yang diketahui, jumlah pekerjaan pelaku paling banyak sopir (11.4\%) dan yang paling sedikit adalah pembantu kantin, petugas bandara, pemotong kayu, petugas cuci mobil, pemulung, karyawan, atau tentara $(0,7 \%)$.

Tabel 12. Distribusi Frekuensi Kasus Kekerasan Seksual Periode 1 Januari 2012-31 Desember 2016 Berdasarkan Hubungan Korban dan Pelaku.

\begin{tabular}{ccc}
\hline Hubungan & Frekuensi & \% \\
\hline Pacar & 38 & 27.1 \\
Bos & 2 & 1.4 \\
Kakak Ipar & 2 & 1.4 \\
Ayah & 5 & 3.6 \\
Kandung & & \\
Kakek & 2 & 1.4 \\
Teman Ibu & 2 & 1.4 \\
Sepupu & 1 & 0.7 \\
Teman & 23 & 16.4 \\
Anggota & 6 & 4.3 \\
Keluarga & & \\
Tidak & 22 & 15.7 \\
Diketahui & & \\
Suami & 1 & 0.7 \\
Tetangga & 21 & 15.0 \\
Dukun & 1 & 0.7 \\
Ayah Tiri & 7 & 5.0 \\
Paman & 7 & 5.0 \\
Total & 140 & 100.0 \\
\hline
\end{tabular}

Pada tabel 12 dapat dilihat bahwa pelaku kekerasan seksual yang terbanyak adalah pacar korban sebanyak 38 kasus (27.1\%), sedangkan yang paling sedikit merupakan dukun, sepupu, atau suami korban dengan masingmasingnya sebanyak 1 kasus $(0.7 \%)$. Berdasarkan kepustakaan, bahwa pelaku yang melakukan kekerasan merupakan orang yang dikenal oleh korban sebanyak $68 \%$, dengan $34 \%$ adalah orangtua kandung. Pelaku yang dikenal tersebut diantaranya pacar, teman, orang tua tiri/kandung, kakek,

44 Taufik Hidayat, Rika Susanti, Citra Manela, Noverika Winda Sari, Abdullah Arief Syahputra Bagian / KSM Ilmu Kedokteran Forensik Fakultas Kedokteran Unand / RSUP dr. M. Djamil Padang Sumatera Barat Indonesia 
tetangga rumah, abang ipar, guru, sepupu namun terdapat beberapa kasus dilakukan oleh orang yang tidak dikenal korban, atau baru dikenal oleh korban. [37] Kepustakaan lain juga menemukan dari 16 kasus kekerasan seksual yang diteliti, hanya satu kasus dilakukan oleh orang yang tidak dikenal oleh korban, sedangkan 15 kasus sisanya dilakukan oleh orang yang dikenal korban seperti pacar, tetangga, guru, teman, bahkan keluarga terdekat korban seperti ayah kandung/tiri, ataupun kakek korban. [38] Dalam catatan kekerasan terhadap perempuan tahun 2017 ditemukan bahwa pacar adalah pelaku kekerasan seksual terbanyak dalam ranah pribadi. Hal ini selaras dengan hasil penelitian dimana pelaku terbanyak adalah pacar korban, yang dalam hal ini diartikan memiliki hubungan dekat dengan korban. [22]

Tabel 13. Distribusi Frekuensi Kasus Kekerasan Seksual Periode 1 Januari 2012-31 Desember 2016 Berdasarkan Frekuensi Berhubungan Badan dengan Pelaku Sebelumnya.

\begin{tabular}{ccc}
\hline $\begin{array}{c}\text { Frekuensi } \\
\text { Hubungan } \\
\text { Badan }\end{array}$ & Frekuensi & Persentase \\
\hline Pertama Kali & 32 & 22.9 \\
Sering & 49 & 35 \\
Tidak Ada & 21 & 15 \\
Tidak Diketahui & 38 & 27.1 \\
Total & 140 & 100 \\
\hline
\end{tabular}

Tabel 13 memberikan data sehingga dapat diketahui sebagian besar korban (35\%) mengaku sering berhubungan badan dengan pelaku sebelumnya. Sedangkan beberapa korban mengaku tidak ada melakukan hubungan seksual dengan pelaku (15\%). Penelitian ini juga menunjukkan bahwa sebagian besar korban mengaku sering berhubungan badan dengan pelaku yaitu sebanyak 35\%. Temuan ini serupa dengan penelitian yang menemukan peristiwa kekerasan seksual bisa muncul sekali saja tapi seringkali terus-menerus. Kekerasan seksual yang pelakunya dikenal oleh korban, memiliki kesempatan besar untuk mengalami kekerasan seksual secara berulang kali dalam kurun waktu lama. Hal ini disebabkan karena pelaku tidak berani menyirapkan rahasia perihal tindakan seksual tersebut kepada orang lain termasuk keluarga sendiri, dikarenakan adanya ancaman, kehormatan dan pemberian argumen dari pelaku kepada korban bahwa tindakan tersebut adalah tanda cinta pelaku kepada korban. [41]

\section{KESIMPULAN}

Temuan kejadian kekerasan seksual pada korban yang dibuatkan visum di RSUP Dr. M Djamil pertahunnya bervariasi, kasus pada tahun 2015 dengan jumlah 39 kasus dan kasus terjarang pada tahun 2013 berjumlah 19 kasus. Jenis kekerasan seksual terbanyak yang ditemukan adalah perkosaan diikuti suka sama suka, cabul dan sodomi atau anal. Perempuan adalah korban seksual terbanyak, sedangkan berdasarkan usia, anak-anak merupakan korban tersering dengan rentang usia terbanyak adalah usia anak-anak. Sebanyak 86 orang korban

45 Taufik Hidayat, Rika Susanti, Citra Manela, Noverika Winda Sari, Abdullah Arief Syahputra Bagian / KSM Ilmu Kedokteran Forensik Fakultas Kedokteran Unand / RSUP dr. M. Djamil Padang Sumatera Barat Indonesia 
kekerasan seksual berstatus sebagai pelajar, terbanyak adalah pelajar SMP. Dari 140 total kasus kekerasan seksual yang dilaporkan, hampir sebagian besarnya tidak mengakibatkan kehamilan yaitu sebanyak 129 kasus.

Pemeriksaan selaput dara pada seluruh korban perempuan didapatkan hasil selaput dara utuh $17,1 \%$, robekan lama $54,3 \%$, robekan baru $10 \%$ dan yang membutuhkan perawatan medis sejumlah 1 kasus $(0.7 \%)$. Pemeriksaaan anus pada 6 kasus dan ditemukan satu korban dengan kemerahan pada anus. penggunaan lidi dalam satu kasus. Bukti adanya persetubuhan dapat dinilai dengan adanya tanda penetrasi dan ejakulasi, salah satunya dengan pemeriksaan sperma maupun komponen mani. Pada 35 korban yang dilakukan pemeriksaan laboratorium ditemukan adanya sperma pada 9 korban dan pada 26 korban lainnya tidak ditemukan adanya sperma. Hasil pemeriksaan genitalia luar didapatkan kemerahan $15 \%$, luka robek $5 \%$, tidak terdapat luka $70,7 \%$ dan luka lecet sebanyak 9,3\%. Didapatkan 9 kasus yang dilakukan pemeriksaan tanda kekerasan dan ditemukan adanya luka memar pada 5 korban (3.6\%), luka lecet pada 2 korban (1.4\%), dan luka terbuka pada 1 korban $(0.7 \%)$.

Usia pelaku terbanyak pada penelitian ini adalah dewasa yang mana pacar adalah pelaku kekerasan seksual terbanyak dalam ranah pribadi. Sebagian besar pelaku merupakan tamatan SMA, sedangkan untuk jenis pekerjaan yang diketahui diantaranya bekerja sebagai supir, pelajar, dan swasta. Penelitian ini juga menunjukkan bahwa sebagian besar korban mengaku sering berhubungan badan dengan pelaku yaitu sebanyak $35 \%$.

Saran untuk instansi berhubungan dengan kesehatan, terkhusus rumah sakit untuk lebih menitikberatkan kuantitas dan kualitas dari sarana prasarana pemeriksaan penunjang, terutama untuk korban kekerasan seksual yang terjadi pada anak, diharapkan semakin dapat membantu proses peradilan. Teruntuk orang tua pada zaman maju saat ini, lebih memberikan pendidikan seksual atau pendidikan kesehatan terkait reproduksi bagi anak-anak seawal mungkin.

\section{DAFTAR PUSTAKA}

[1] Susanti R, Manela C, Hidayat T., 2017. Modul Forensik Pemeriksaan Kekerasan Seksual. Bagian Kedokteran Forensik dan Medikolegal FK. Universitas Andalas : Padang

[2] Kristiani Ni Md, 2014. Kekerasan Kekerasan Seksual Ditinjau Dari Perspektif Kriminologi, Magister Hukum Universitas Udayana. Vol.7 No.3. Hal 371-381.

[3] Lembar Fakta Catatan Tahunan (CATAHU) Komnas Perempuan Tahun 2018. Komnas Ham perempuan. Diakses 5 mei 2018, pukul 23.00https://www.komnaspere mpuan.go.id/file/pdf_file/2017 \%20Siaran\%20Pers/Lembar\%2 0Fakta\%20Catahu\%202018.pd $\underline{f}$ 
[4] Cattaneo C, Ruspa M, Motta T, Gentilomo A, Scagnelli C. Child sexual abuse: An Italian perspective. Am J Forensic Med Pathol. 2007; 28 : 163-7.

[5] Savino JO, Turvey BE. Defining Rape and Sexual assault. In : Savino JO, Turvey BE, editors. Rape Investigation handbook. USA : Elsevier.Inc. ; 2005. p.1-22.

[6] Budijanto A, Sudiono S, Purwadianto A. Kekerasan seks dan aspek medikolegal gangguan psiko seksual. Jakarta : Kalman Media Pusaka; 1982. p. 5-34.

[7] Smith MD, ed. Encyclopedia of Rape. Wesport (CT) : 2004. p. 169.

[8] Atmadja DS. Aspek medikolegal Pemeriksaan Korban Perlukaan dan Keracunan di Rumah Sakit. In : Prosiding Simposium Tata laksana Visum et Repertum Korban Hidup pada Kasus Perlukaan dan Keracunan di Rumah Sakit; Tahun 2004, Jun 23; Jakarta; 2004. p. 1-5.

[9] World Health Organization Guidelines for Medico-legal Care for Victims of Sexual Violence. Geneva : WHO; 2003. p. 17-55.

[10] Rogers D, Newton M. Sexual assault examination. In : Stark $\mathrm{MM}$, editor. Clinical forensic medicine : A physician's guide. 2nd ed. Totowa (NJ) : Humana Press Inc. ; 2005. p. 61-126.

[11] National Center for Women \& Policing. Successfully investigating acquaintance sexual assault : A national training manual for law enforcement. [cited 2008 May 21]. Available from: http://www.mincava.umn.edu/d ocuments/acquaintsa/participan t/allegations. pdf.

[12] Lestari NP. Kecakapan bertindak dalam melakukan perbuatan hukum setelah berlakunya UU. No. 30 tahun 2004 perihal Jabatan Notaris. [Unpublished thesis] [cited 2012 Jul 10]. Available from: http://eprints.undip.ac.id/18403 /1/ Ningrum_Puji_Lestari.pdf.

[13] Linden JA, Lewis-O'Connor A, Jackson MC. Forensic examination of adult victims and perpetrators of sexual assault. In: Olshaker JS, Jackson MC, Smock WS, editors. Forensic emergency medicine. 2nd ed. USA: Lippincott Williams \& Wilkins; 2007. p. 86-125.

[14] Idries AM. Sistematik Pemeriksaan Kedokteran Forensik khusus pada Korban Kekerasan Seksual. In : Idries AM, Tjiptomartono AL, editors. Penerapan Ilmu Kedokteran Forensik dalam proses penyidikan. Jakarta: CV. Sagung Seto; 2008. p. 113-32.

[15] Anil Aggrawal's Internet Journal of Forensic Medicine and Toxicology. 2001; 2(2) [cited 2012 Jul 10]. Available from:

http://www.anilaggrawal.com/ij /vol_002_no_002/reviews/tb/pa ge008.html

[16] Le Beau M, Mozayani A. Collection of evidence from DSFA. In: LeBeau M,

47 Taufik Hidayat, Rika Susanti, Citra Manela, Noverika Winda Sari, Abdullah Arief Syahputra Bagian / KSM Ilmu Kedokteran Forensik Fakultas Kedokteran Unand / RSUP dr. M. Djamil Padang Sumatera Barat Indonesia 
Mozayani A, editors. Drugfacilitated sexual assault : A forensic handbook. UK : Academic Press; 2001. p. 197209.

[17] Smock WS, Besant-Matthews PE. Forensic Photography in The Emergency Department. In : Olshaker JS, Jackson MC, Smock WS, editors. Forensic emergency medicine. 2nd ed. USA : Lippincott Williams \& Wilkins; 2007. p. 268-91.

[18] Arios R, Tomuka D, Kristanto E. Efektivitas Deteksi Spermatozoa Menggunakan Pewarnaan Malachite Green, Jurnal e-CliniC (eCl), vol.2, no. $2: 2014$.

[19] Rights of the Child: The meaning of the child and the rights of the children. https://www.humanium.org/en/ child-rights/ - Diakses April 2018.

[20] UNICEF. The Convention On The Rights of The Child, Guiding Principles. https://www.unicef.org/crc/files /Guiding Principles.pdf

Diakses April 2018.

[21] WHO. Definition of Key Terms. http://www.who.int/hiv/pub/gui delines/arv2013/intro/keyterms/ en/ - Diakses April 2018.

[22] NICE (2009). When to Suspect Child Maltreatment. National Collaborating Centre for Women's and Children's Health (UK). London.

[23] Macdonald G, Livingstone N, Hanratty J, et al (2016). The effectiveness, acceptability and cost-effectiveness psychosocial interventions for maltreated children and adolescents: an evidence synthesis. Southampton (UK): NIHR Journals Library

[24] Petersen AC, Joseph J, Feit M (2014). New Directions in Child Abuse and Neglect Research. Institute of Medicine; National Research Council. Washington (DC): National Academies Press (US).

[25] Who (2017). Responding to Children and Adolescents Who Have Been Sexually Abused : WHO Clinical Guidelines. Geneva.

[26] WHO (2003). Guidelines for Medico-Legal Care of Victims of Sexual Violence. http://apps.who.int/iris/bitstrea $\mathrm{m} / 10665 / 42788 / 1 / 924154628 \mathrm{X}$ .pdf - Diakses April 2018.

[27] D2L (2017). Child Sexual Abuse Statistics. https://www.d21.org/wpcontent/uploads/2017/01/all_sta tistics_20150619.pdf - Diakses April 2018. Savino JO, Turvey BE. Defi ning rape and sexual assault. In: Savino JO, Turvey BE, editors. Rape investigation handbook. USA: Elsevier Inc.; 2005. p. 1-22.

[28] Cattaneo C, Ruspa M, Motta T, Gentilomo A, Scagnelli C. Child sexual abuse: An Italian perspective. Am J Forensic Med Pathol. 2007; 28 : 163-7.

[29] Smith MD, ed. Encyclopedia of rape. Wesport (CT) : 2004. p. 169.

[30] Budijanto A, Sudiono S, Purwadianto A. Kekerasan seks

48 Taufik Hidayat, Rika Susanti, Citra Manela, Noverika Winda Sari, Abdullah Arief Syahputra Bagian / KSM Ilmu Kedokteran Forensik Fakultas Kedokteran Unand / RSUP dr. M. Djamil Padang Sumatera Barat Indonesia 
dan aspek medikolegal gangguan psikoseksual. Jakarta: Kalman Media Pusaka; 1982. p. 5-34.

[31] Vanwesenbeeck I. 2008. Sexual violence and the MDGs. International jornal of sexual health. Vol 20; pp 25-49.

[32] Indrayana TM. 2017. Profil Kasus Kekerasan Seksual terhadap Perempuan dan Anak yang Diperiksa di Rumah Sakit Bhayangkara Dumai. Jurnal kesehatan Melayu. p. 9-13

[33] Wijaya ck, Henky, Alit IBT. 2017. Gambaran Bukti Medis Kasus Kekerasan Seksual yang Diperiksa di Bagian Ilmu Kedokteran Forensik RSUP Sanglah Periode Januari 2009 Desember 2013. E-Jurnal Medika. Vol 6 (9). p. 1-6

[34] Komisi Nasional Anti Kekerasan Terhadap Perempuan. Tergerusnya Ruang Aman Perempuan Dalam Pusaran Politik Populisme.

https//komnasperempuan.go.id/ File/Pdf_File/2018/Publikasi/C atatan\%20tahunan\%20kekerasa n\%20terhadap\%20perempuan $\% 202018$. Diakses Tanggal 8 Mei 2018

[35] Humaira D, Rohmah N, Rifanda N, Novitasari K. 2015. Kekerasan Seksual Pada Anak: Telaah Relasi Pelaku Korban Dan Kerentanan Pada Anak. Jurnal psikoislamika. Vol 12 (2), p. $1-10$

[36] Undang-Undang Nomor 31 Tahun 2014 tentang Perubahan Atas Undang-Undang Nomor
13 Tahun 2006 tentang Perlindungan Saksi dan Korban [37] Undang - Undang Nomor 11 Tahun 2012 Tentang Sistem Peradilan Anak.

[38] Undang - Undang Nomor 35 Tahun $2014 \quad$ Tentang Perubahan Atas. Undang Undang Nomor 23 Tahun 2002 Tentang Perlindungan Anak.

[39] Brown KP, Sommers MS. Injury and Forensic Examination of The Victim. In: Practical Aspect of Rape Inverstigation, A Multidisciplinary Approach. Fouth Edition. Hazelwood RR, Burgess AW, editors. Boca Raton: CRC Press, 2009

[40] Karafil R, Keten a, Zeren C, Arslan MM, Eren A. Evaluation of sexual assault in Turkey. Journal of Forensic and Legal Medicine. 2013 Mar; $20: 404-7$

[41] Marcheyla S. Perbuatan Kekerasan atau Pelecehan Seksual terhadap Perempuan. Lex at societhtis. 2013. Vol 1(2). p. 39-49

[42] Ingesmann-Hansen O, Sabroe $\mathrm{S}$, Brink $\mathrm{O}$, Knudsen $\mathrm{M}$, Charles AV. 2008. Characteristic of Victims and Assaults of Sexual ViolenceImproving Inquiries and Prevention. Journal of Forensic and Legal Medicine. Volume 16(10). p. $182-8$

[43] Fajrina DD. 2012. Resiliensi pada Remaja Putri yang Mengalami Kehamilan Tidak Diinginkan Akibat kekerasan Seksual. Jurnal Penelitian dan 
Pengukuran Psikologi. Vol 1 (1). p. 55-56

[44] Kalangit A, Mallo J, Tomuka D. 2013. Peran Ilmu Kedokteran Forensik Dalam Pembuktian Tindak Pidana Pemerkosaan Sebagai Kekerasan Kekerasan Seksual. https:// ejournal .unsrat.ac.id/index.php/eclinic/a rticle/ view/4861. Diakses tanggal 8 Mei 2018

[45] Budiyanto A, Widiatmaka W, Sudiono S, Mun'im WA, Sidhi, Hertian S, Sampurna B. 1997. Pemeriksaan Medik pada Kasus Kekerasan Seksual dalam: Ilmu Kedokteran Forensik. Bagian kedokteran Forensik Fakultas Kedokteran Universitas Indonesia. Jakarta; p. $147-158$

[46] Sturgis EA, TysonAa, Parekh V. 2010. Characteristics of sexual assaults in which adult victims report penetration by a foreign object. Journal of Forensic and Legal Medicine. Vol 17 (10) p. 140-142

[47] Carey B, Healy C, Elder DE. 2010. Foreign body sexual assault complicated by rectovaginal fistula; a case report. Journal of Forensic and Legal Medicine. Vol 17 (10). p. 161-163

[48] Pungoh A, Mallo J, Siwu J. 2013. Pola Kekerasan Pada Korban Kekerasan Seksual Yang Meninggal Dan Di Periksa Di Rsup Prof. Dr. R. D. Kandou Manado. Https://Ejournal. Unsrat.Ac.Id/Index.Php/Eclinic
/Article/View/3298. Diakses Tanggal 8 Mei 2018

[49] Anggreiny N, Sari SM, Aziza A. 2016. Mekanisme Psikologis Remaja Pelaku Kekerasan Seksual. Jurnal Pemikiran dan Penelitian Psikologi. Vol 11 (3). p. 11222.

[50] Marsa F, O'Reilly, G Car, Murphy P. Attachment styles and psychological profiles of child sec offenders in Ireland. 2004. Journal of Interpersonal Violence, 19. p. 1-24

[51] Gani HA. Kekerasan terhadap Anak; Tinjauan dari Sisi Pelaku (Studi di Wilayah Kabupaten Jember). 2011. Departemen Promosi Kesehatan dan Ilmu Perilaku Fakultas Kesehatan MAsyarakat Universitas Jember.

[52] Suyanto B, Hariadi S, dan Nugroho PA. 2000. tindak Kekerasan terhadap Anak. Surabaya: Lutfansah Mediatama

[53] Ulum PN, Lestari S, dan Hertinjung WS. 2010. Romantisme Wanita Korban Kekerasan Seksual pada Masa Kanak-Kanak. Indigenous, Jurnal Ilmiah Berkala Psikologi. Vol 12 (2). p. 126136. 